\title{
PENGARUH MODAL SOSIAL TERHADAP PRODUKTIVITAS USAHATANI KOPI DI LMDH KARAMAT JAYA KECAMATAN CISURUPAN KABUPATEN GARUT
}

\section{THE INFLUENCE OF SOCIAL CAPITAL ON COFFE FARMING PRODUCTIVITY AT LMDH KARAMAT JAYA CISURUPAN DISTRICT GARUT REGENCY}

\author{
Vini Aisyah Aminingrum*, Ahmad Choibar Tridakusumah \\ Program Studi Agribisnis, Fakultas Pertanian, Universitas Padjadjaran \\ *Email: viniaisyah230@gmail.com \\ (Diterima 28-11-2021; Disetujui 22-01-2022)
}

\begin{abstract}
ABSTRAK
Penelitian ini bertujuan untuk menganalisis pengaruh modal sosial terhadap produktivitas petani kopi di LMDH Karamat Jaya Desa Karamatwangi Kecamatan Cisurupan Kabupaten Garut. Penelitian dilakukan pada bulan September 2020 sampai dengan Januari 2021. Desain penelitian menggunakan penelitian kuantitatif dengan metode survei, serta menggunakan analisis Regresi Linear Berganda. Responden penelitian berjumlah 63 sampel dengan populasi sebanyak 167 petani kopi. Hasil penelitian menunjukan bahwa mayoritas petani di LMDH Karamat Jaya memiliki produktivitas yang cenderung rendah dengan 48 petani masih di bawah rata-rata produktivitas $993,8 \mathrm{~kg} / \mathrm{ha} / \mathrm{tahun}$. Modal sosial yang dimiliki petani kopi di LMDH Karamat Jaya tinggi dilihat dari aspek kepercayaan, jaringan, pertisipasi, norma sosial, dan timbal balik. Dimensi modal sosial yang sangat tinggi yaitu dimensi kepercayaan (trust). Hasil analisis linear berganda diperoleh bahwa kepercayaan, partisipasi, dan norma sosial berpengaruh nyata terhadap produktivitas petani kopi. Variabel-variabel yang tidak berpengaruh terhadap produktivitas petani kopi yaitu jaringan dan timbal balik.
\end{abstract}

Kata Kunci: Kepercayaan, Modal Sosial, Petani Kopi, Produktivitas

\section{ABSTRACT}

This study aims to analyze the effect of social capital on the productivity of coffee farmers at LMDH Karamat Jaya, Cisurupan District, Garut Regency. This research design uses quantitative research with survey methods, and uses Multiple Linear Regression analysis. Respondents of this study amounted to 63 samples with a population of 167 coffee farmers. The results showed that the majority of farmers in LMDH Karamat Jaya had low productivity with 48 farmers still below the average productivity of 993,8 $\mathrm{kg} / \mathrm{ha} /$ year. The social capital owned by coffee farmers in LMDH Karamat Jaya is high in terms of trust, network, participation, social norms, and reciprocity. The very high dimension of social capital is the dimension of trust. The results of multiple linear analysis show that trust, participation, and social norms have a significant effect on the productivity of coffee farmers. The variables that have no effect on the productivity of coffee farmers are network and reciprocity.

Keywords: Coffee Farmers, Farmer Productivity, Social Capital, Trust

\section{PENDAHULUAN}

Pembangunan merupakan proses transformasi jangka panjang yang selama ini dilihat dari perkembangan dan pertumbuhan ekonomi. Modal pembangunan terdiri atas modal alam, modal fisik, modal manusia dan terdapat modal lain yang juga dapat berkontribusi 
dalam menunjang pembangunan yakni modal sosial (Grootaert, 2001).

Indeks modal sosial di Jawa Barat sendiri pada tahun 2017 yaitu 44,73\% dan memiliki nilai yang lebih rendah dibandingkan dengan indeks modal sosial yang dimiliki oleh Indonesia yaitu 47,56\%. Nilai indeks modal sosial Jawa Barat yang masih terbilang rendah karena berada di urutan ke 24 dari 33 provinsi pada indeks modal sosial di Indonesia sehingga perlu adanya peningkatan modal sosial di Jawa Barat agar dapat dijadikan modal pembagunan (BPS, 2017).

Kondisi modal sosial di pedesaaan berbeda dengan modal sosial di perkotaan, modal sosial di pedesaan lebih tinggi dibandingkan dengan modal sosial di perkotaan. Perbedaan tersebut dicirikan dengan masyarakat pedesaan yang sistem kehidupan biasanya berkelompok atas dasar sistem kekeluargaan berbeda dengan masyarakat perkotaan yang pada umumnya dapat mengurus dirinya sendiri tanpa harus bergantung kepada orang lain (Soekanto, 2015).

Sebagian besar mata pencaharian penduduk Desa Karamatwangi yaitu di bidang pertanian dengan jenis tanaman yang diproduksi berupa tanaman hortikultura, dan sebagian penduduk Desa Karamatwangi menanam kopi terutama jenis kopi arabika. Diketahui bahwa Desa Karamatwangi berada di kawasan gunung berapi aktif dengan unsur hara tanah yang lebih komplek, maka cita rasa kopi arabikanya memiliki keunikan tersendiri. Lahan perkebunan kopi yang dikelola masyarakat di $\mathrm{LMDH}$ Karamat Jaya yang berada di Desa Karamatwangi ini sejak 2005 telah mengelola 159 hektar tanah kehutanan yang melibatkan 660 kepala keluarga petani (LMDH Cisurupan, 2020). Melihat potensi utama Desa Karamatwangi pada bidang pertanian dan merupakan jalur utama menuju Taman Wisata Alam Kawah Papandayan, maka perlu ada peran lembaga pertanian dalam pengembangan potensi tersebut guna menunjang perekonomian desa dan adanya peningkatan produktivitas petani terutama petani kopi.

Salah satu permasalahan yang dihadapi oleh petani kopi di LMDH Karamat Jaya yaitu rendahnya produktivitas kopi dengan baru mencapai kurang dari 1 ton/ha/tahun (LMDH, 2020). Hal tersebut masih tergolong rendah seharusnya potensi produktivitas tanaman kopi arabika mencapai 1,2 ton/ha/tahun (Kementan, 2019). 
Usaha peningkatan produktivitas petani dapat dilakukan dengan meningkatkan modal. Pentingnya peranan modal dapat membantu meningkatkan produktivitas pertanian, namun tidak banyak orang mengakui bahwa bertambahnya modal manusia dan modal sosial akan menaikan produktivitas (Mubyarto, 1986).

Kelembagaan pertanian juga menjadi salah satu wadah modal sosial bagi para petani secara berkesinambungan. Maka dari itu, dapat dipahami bahwa kelembagaan petani dengan modal sosial sangat terkait dengan proses peningkatan produktivitas petani. Berdasarkan uraian tersebut, maka peneliti tertarik untuk meneliti pengaruh modal sosial terhadap produktivitas petani kopi di LMDH Karamat Jaya Kecamatan Cisurupan Kabupaten Garut.

\section{METODE PENELITIAN}

\section{Tempat dan Objek Penelitian}

Objek dalam penelitian ini adalah modal sosial pada petani kopi di LMDH Karamat Jaya dan bagaimana pengaruhnya terhadap produktivitas. Tempat yang dipilih sebagai lokasi penelitian adalah Desa Karamatwangi Kecamatan Cisurupan Kabupaten Garut Jawab Barat. Kecamatan Cisurupan merupakan salah satu produksi terbesar kopi arabika di Kabupaten Garut. Desa Karamatwangi merupakan desa yang berada di Kecamatan Cisurupan dengan produksi kopi yang dihasilkan berjumlah 103,6 ton, produksi tersebut tertinggi dibandingkan dengan desa-desa sekitar. Desa Karamatwangi terdapat Lembaga Masyarakat Desa Hutan bernama LMDH Karamat Jaya. LMDH Karamat Jaya memiliki merupakan Lembaga yang dibentuk oleh masyarakat desa yang berada di dalam atau sekitar hutan untuk mengatur dan memenuhi kebutuhan melalui interaksi terhadap hutan dalam konteks sosial, ekonomi, politik dan budaya. LMDH memiliki peranan penting sebagai wadah bagi para petani kopi untuk mengembangkan potensi diri guna memenuhi kebutuhan bersama dengan nilai dan aturan bersama.

\section{Desain Penelitian}

Desain penelitian yang digunakan dalam penelitian ini adalah penelitian kuantitatif. Penelitian kuantitatif merupakan desain penelitian yang digunakan untuk meneliti pada populasi atau sampel tertentu, pengumpulan data menggunakan instrumen penelitian, analisis data bersifat kuantitatif statistik dengan tujuan untuk menguji hipotesis yang telah ditetapkan (Sugiyono, 2015). 
Metode penelitian yang digunakan pada penelitian ini adalah metode penelitian survei.

\section{Variabel Penelitian}

Variabel yang digunakan dalam penelitian ini adalah sebagai berikut:

1. Produktivitas yang dipakai adalah output produksi dibagi dengan luas lahan yang dimiliki oleh petani.

2. Kepercayaan adalah rasa saling percaya terhadap antar sesama petani di LMDH Karamat Jaya. Rasa percaya dapat diukur dengan mengamati tingkat kepercayaan terhadap sesama petani dan kepercayaan terhadap kelompok tani.

3. Partisipasi adalah peran aktif masingmasing petani dalam sebuah kegiatan.

4. Jaringan adalah sekumpulan orang yang bekerjasama dan mempunyai tujuan bersama yang berinteraksi satu sama lain untuk mencapai tujuan bersama.

5. Peran norma sosial adalah kepatuhan anggota kelompok tani di dalam memenuhi aturan norma yang ada.

6. Timbal balik (resiprocity) merupakan bentuk sikap memberi, saling menerima dan saling membantu yang dapat muncul dari interaksi sosial yang ada pada setiap kelompok dan lembaga pertanian.
7. Jumlah tanaman, satuan pohon yang sedang dalam proses pertumbuhan dan belum dapat dipanen atau diambil hasilnya (pohon).

\section{Teknik Penarikan Sampel}

Penentuan jumlah sampel didasarkan pada metode slovin dengan jumlah populasi dan toleransi kesalahan (a) 10\% (Sarwono, 2006). Populasi yang digunakan adalah seluruh anggota kelompok tani yang tergabung pada LMDH Karamat Jaya. Jumlah populasi pada kelompok tani yaitu 167 orang. Berdasarkan rumus slovin maka ukuran sampel yang digunakan sebagai berikut:

$$
\begin{gathered}
n=\frac{N}{1+N(a)^{2}} \\
n=\frac{167}{1+167(0,1)^{2}} \\
n=63
\end{gathered}
$$

Keterangan :

$n=$ Ukuran sampel

$N=$ Ukuran Populasi

$\alpha=$ standar error yang digunakan $10 \%$

Hasil perhitungan sampel menggunakan rumus slovin didapatkan sebuah sampel yang berukuran 63 orang anggota LMDH Karamat Jaya sebagai responden.

\section{Teknik Pengumpulan Data}

Teknik pengumpulan data yang digunakan dalam penelitian ini yaitu wawancara, observasi, kuesioner dan 
kepustakaan. Wawancara merupakan teknik pengumpulan data dengan tanya jawab yang dilakukan untuk memperoleh informasi dan pengetahuan, responden diberikan pertanyaan yang sama dengan panduan kuesioner. Observasi merupakan teknik yang dilakukan dengan mengadakan pengamatan langsung terhadap objek yang akan diteliti. Observasi memerlukan pencatatan dan perekaman yang detail terhadap perilaku informan tentang apa yang terjadi didalam tempat penelitian secara spesifik.

Kuesioner adalah cara memberikan pertanyaan tertulis kepada responden untuk di jawabnya. Kepustakaan merupakan teknik pengumpulan data dengan menggunakan literatur yang berkaitan dengan penelitian. Sumber data bisa didapat dari jurnal, skripsi, BPS, Dinas Pertanian, Outlook Tanaman Hortikultura, dan media informasi lainnya yang berkaitan dengan penelitian.

\section{Metode Analisis}

Metode analisis yang digunakan adalah analisis regresi linear berganda (OLS). OLS atau analisis regresi berganda merupakan teknik analisis data untuk menganalisis hubungan antara variabel dependen dengan variabel independen. Dalam penelitian ini, metode OLS digunakan untuk mengetahui pengaruh modal sosial terhadap produktivitas kopi. Model OLS dalam penelitian ini adalah sebagai berikut.

$$
\begin{aligned}
\mathbf{Y}= & \boldsymbol{\beta}_{0}+\boldsymbol{\beta}_{1} \mathbf{X}_{1}+\boldsymbol{\beta}_{2} \mathbf{X}_{2}+\boldsymbol{\beta}_{3} \mathbf{X}_{3}+\boldsymbol{\beta}_{4} \mathbf{X}_{4}+ \\
& \boldsymbol{\beta}_{5} \mathbf{X}_{5}+\varepsilon
\end{aligned}
$$

Keterangan :

$Y_{j}=$ Produktivitas petani

$\beta_{0}=$ Konstanta

$\beta_{1}=$ Koefisien regresi dari variabel kepercayaan

$X_{1}=$ Kepercayaan

$\beta_{2}=$ Koefisien regresi dari variabel jaringan

$X_{2}=$ Jaringan

$\beta_{3}=$ Koefisien regresi dari variabel norma sosial

$X_{3}=$ Norma sosial

$\beta_{4}=$ Koefisien regresi dari variabel partisipasi

$X_{4}=$ Partisipasi

$\beta_{5}=$ Koefisien regresi dari variable timbal balik

$X_{5}=$ Timbal Balik

$\varepsilon=$ Standard eror

\section{HASIL DAN PEMBAHASAN}

\section{Produktivitas Usahatani Kopi}

Hasibuan (2003) mengartikan bahwa produktivitas merupakan perbandingan antara output (hasil) dengan input (masukan). Untuk produktivitas petani kopi di LMDH Karamat Jaya diukur dengan melakukan perbandingan antara hasil produksi dan luas lahan. Produktivitas usahatani kopi terendah yaitu $50 \mathrm{~kg} / \mathrm{ha} /$ tahun dan tertinggi yaitu $8.333 \mathrm{~kg} / \mathrm{ha} /$ tahun. Adapun 
rata-rata produktivitas Usahatani kopi di LMDH Karamat Jaya yaitu 993,8 $\mathrm{kg} / \mathrm{ha} /$ tahun. Tabel 1 merupakan kategori produktivitas Usahatani kopi di LMDH Karamat Jaya.

Tabel 1. Produktivitas Usahatani Kopi di LMDH Karamat Jaya

\begin{tabular}{lccc}
\hline No. & Produktivitas & $\begin{array}{c}\text { Jumlah } \\
\text { (orang) }\end{array}$ & $\begin{array}{c}\text { Persentase } \\
(\%)\end{array}$ \\
\hline 1. & Tinggi & 15 & 23,8 \\
2. & Rendah & 48 & 76,2 \\
\hline & Total & 63 & 100 \\
\hline
\end{tabular}

Berdasarkan Tabel 1 mayoritas produktivitas kopi di LMDH Karamat Jaya berada di kategori rendah yaitu sebanyak 48 orang $(76,2 \%)$. Sebanyak 15 orang $(23,8 \%)$ dengan produktivitas tinggi. Dengan demikian, produktivitas kopi di LMDH Karamat Jaya Karamat Jaya Desa Karamatwangi Kecamatan Cisurupan Kabupaten Garut mayoritas rendah. Sebanyak $76,2 \%$ petani masih di bawah rata-rata produktivitas kopi LMDH yaitu 993,8 kg/ha/tahun. Potensi produktivitas kopi arabika bisa mencapai $2.500 \mathrm{~kg} / \mathrm{ha} /$ tahun (Puslitbangbun, 2015). Belum optimalnya penggunaan lahan usahatani bisa menjadi salah satu alasannya. Petani di Desa Karamatwangi sendiri masih banyak melakukan menanam kopi dengan sistem tanam tumpangsari dengan tanaman sayuran sehingga populasi tanaman kopi masih dalam cenderung rendah yang akan berpengaruh terhadap produksi kopi.

Penyebab lain adanya penurunan produktivitas yaitu diakibatkan oleh Organisme Pengganggu Tanaman (OPT) utama yang menyerang tanaman kopi, ialah hama penggerek buah kopi (Hypothenemus hampei), kutu dompolan atau kutu putih (Planococcus citri), kutu hijau (Coccus viridis) atau kutu coklat (Saesetia coffea). Beberapa penyakit utama pada kopi adalah jamur upas, busuk buah, busuk cabang, dan karat daun. Menurut penelitian Wiryadiputra, salah cara meningkatkan produktivitas dengan menghindari penyakit karat daun pada kopi arabika salah satunya adalah melalui penanaman pada lahan dengan ketinggian yang cukup yaitu di atas 1.000 mdpl.

\section{Pengaruh Modal Sosial Terhadap Produktivitas Usahatani Kopi}

Berikut merupakan analisis regresi linear berganda pengaruh modal sosial terhadap produktivitas usahatani kopi dengan variabel terikat yaitu produktivitas (Y) dan variabel bebas yaitu kepercayaan (X1), partisipasi (X2), jaringan (X3), norma sosial (X4), timbal balik (X5). Dari hasil perhitungan menggunakan SPSS versi 26 didapatkan hasil sebagai berikut Tabel 2 . 
Tabel 2. Hasil Analisis Regresi Linear Berganda

\begin{tabular}{clcc}
\hline No & \multicolumn{1}{c}{ Variabel } & Koefisien & Signifikan \\
\hline 1. & Konstanta $(\mathrm{C})$ & 2,865 & 0,000 \\
\hline 2. & Kepercayaan & 0,648 & 0,007 \\
\hline 3. & Partisipasi & 0,761 & 0,016 \\
\hline 4. & Jaringan & 0,753 & 0,102 \\
\hline 5. & Norma sosial & 0,822 & 0,046 \\
\hline 6. & Timbal balik & 0,511 & 0,302 \\
\hline & R - Square & 0,608 & \\
\hline & Uji F & 17,659 & 0,000 \\
\hline
\end{tabular}

Berdasarkan hasil regresi linear berganda pada Tabel 2 nilai R-square sebesar 0,608. Hal tersebut menunjukkan bahwa $60,8 \%$ variabel produktivitas secara dapat dijelaskan oleh variabel bebas yang digunakan dalam model. Pengaruh modal sosial secara bersamaan untuk model ini dilihat dari nilai uji $\mathrm{F}$. Berdasarkan Tabel 2, nilai uji $\mathrm{F}$ adalah 0,000 dengan tingkat signifikan 0,05 . Maka dapat disimpulkan bahwa variabel kepercayaan, partisipasi, jaringan, norma sosial, dan timbal balik berpengaruh nyata terhadap produktivitas petani kopi di LMDH Karamat Jaya, Desa Karamatwangi, Kecamatan Cisurupan, Kabupaten Garut.

Berdasarkan data pada Tabel 2 nilai signifikansi variabel kepercayaan adalah $0,007<0,05$. Artinya kepercayaan berpengaruh secara siginifikan pada taraf nayat $5 \%$. Setiap penambahan kepercayaan $1 \%$ akan meningkatkan produktivitas petani sebesar $0,6 \%$.
Variabel partisipasi memiliki nilai signifikansi $0,016<0,05$, maka dapat disimpulkan bahwa partisipasi berpengaruh secara signifikan terhadap produktivitas petani pada taraf nyata $5 \%$. Setiap penambahan partisipasi $1 \%$ akan meningkatkan produktivitas petani sebesar $0,76 \%$.

Variabel jaringan memiliki nilai signifikansi $0,102>0,05$, maka dapat disimpulkan bahwa jaringan tidak berpengaruh secara signifikan terhadap produktivitas petani pada taraf nyata $5 \%$.

Variabel norma sosial memiliki nilai signifikansi $0,046<0,05$, maka dapat disimpulkan bahwa norma sosial berpengaruh secara signifikan terhadap produktivitas petani dengan taraf nyata $5 \%$. Setiap penambahan $1 \%$ norma sosial akan meningkatkan produktivitas petani sebesar $0,82 \%$.

Variabel timbal balik memiliki nilai signifikansi $0,302>0,05$, maka dapat disimpulkan bahwa timbal balik tidak berpengaruh secara signifikan terhadap produktivitas petani pada taraf nyata $5 \%$.

Berdasarkan hasil wawancara penggerak utama masyarakat Desa Karamatwangi dalam proses meningkatkan usahatani kopi ialah para tokoh masyarakat di Desa Karamatwangi. Kepercayaan yang tinggi masyarakat 
Desa Karamatwangi terhadap para tokoh masyarakat dapat mempengaruhi pola pikir petani sehingga menciptakan perubahan ke arah yang positif.

Kepercayaan dan keyakinan masyarakat terhadap tokoh masyarakat yang mempunyai nilai-nilai dan normanorma sebagai panutan masyarakat yang dapat mengikat solidaritas sosial dan sebagai acuan menyelesaikan konflik dan penyimpangan yang terjadi di Desa Karamatwangi. Adanya tokoh masyarakat yang disegani dalam suatu kelompok maka aturan yang berlaku akan dilaksanakan dengan sebaik mungkin oleh para petani sesuai arahan dari tokoh masyarakat, ketua kelompok dan ketua LMDH. Hal tersebut juga membuat para petani berpastisipasi aktif dalam kegiatan kelompok salah satunya dikarenakan peran tokoh masyarakat. Menurut Winarni (2011), tingkat partisipasi dalam suatu kelompok bisa disebabkan karena adanya peran tokoh pemimpim yang mampu menggerakkan, menstimulir atau mengkoordinir anggotanya sehingga tingkat partisipasi menjadi tinggi. Adanya partisipasi aktif yang dilakukan para petani dalam kegiatan kelompok seperti mengikuti kegiatan penyuluhan terkait usahatani kopi, penanggulangan HPT perkebunan kopi membuat wawasan para petani tentang kopi semakin bertambah dan meningkatkan produktivitas petani. Selaras dengan penelitian Tambunan (2018) bahwa keterlibatan petani dalam suatu pertemuan-pertemuan kelompok yang diadakan secara rutin dan aktif membuat produktivitas petani meningkat.

Variabel-variabel yang tidak berpengaruh terhadap produktivitas petani kopi di LMDH Karamat Jaya Desa Karamatwangi Kecamatan Cisurupan Kabupaten Garut yaitu jaringan dan timbal balik. Jaringan tidak berpengaruh dikarenakan luasnya jaringan di LMDH Karamat Jaya sebagian besar dilakukan oleh para petinggi seperti tokoh masyarakat, ketua LMDH, kepala desa. Menurut Putnam (2000), seseorang yang memiliki jaringan yang luas akan mampu menguasai banyaknya informasi yang ada. Timbal balik antar petani kopi di LMDH Karamat Jaya berperan penting dalam pembentukan suatu kelompok atau organisasi menjadi lebih baik. Timbal balik tidak berpengaruh terhadap produktivitas dikarenakan oleh tingkat pendidikan dan pengetahuan yang relatif sama antar petani kopi di LMDH Karamat Jaya Hal tersebut menghambat timbulnya mekanisme saling mengingatkan, saling berbagi ilmu. Sejalan dengan penelitian Winarni (2011) 
bahwa rendahnya pengaruh timbal balik disebabkan oleh tingkat pendidikan dan pengetahuan yang relatif sama antar petani sehingga menghambat timbulnya mekanisme saling mengingatkan dikarenakan level yang sama.

Peningkatan produktivitas dipengaruhi oleh modal lainnya selain modal sosial. Adanya modal fisik (physical capital) berupa bibit, pupuk, pestisida dan alat-alat pertanian dan modal manusia berupa kemampuan, keterampilan pengetahuan dan pengalaman petani kopi di LMDH Karamat Jaya akan meningkatkan produktivitas kopi. Akan tetapi perlu juga modal sosial disamping modal lainnya dalam peningkatan produktivitas. Menurut Grootaert (2001) adanya pemberian modal fisik tanpa dikomplemenkan dengan modal sosial diperkirakan tidak akan mendapatkan hasil yang diharapkan. Hal tersebut juga selaras dengan pendapat Glaeser et al (2001) yang menyatakan bahwa modal sosial bersama-sama dengan human capital dan physical capital akan memfasilitasi aktivitas yang produktif.

\section{KESIMPULAN DAN SARAN}

\section{Kesimpulan}

Produktivitas kopi di LMDH Karamat Jaya yaitu sebanyak 993,8 $\mathrm{kg} / \mathrm{ha} /$ tahun, hal tersebut masih di bawah rata-rata produktivitas kopi arabika nasional yang seharusnya di atas 1 ton/ha/tahun. Sebanyak $76,2 \%$ petani kopi di LMDH Karamat Jaya masih di bawah rata-rata produktivitas. Hal tersebut dikarenakan belum optimalnya penggunaan lahan usahatani kopi dan adanya Organisme Pengganggu Tanaman (OPT) yang menyerang tanaman kopi sehingga produktivitas rendah.

Modal sosial yang berpengaruh nyata terhadap produktivitas petani yaitu kepercayaan, partisipasi dan norma sosial. Kepercayaan akan meningkat produktivitas petani melalui rasa percaya yang tinggi untuk membuat kondisi sosial yang aman sehingga tidak perlu menambah biaya untuk menjaga faktorfaktor produksi. Semakin tinggi partisipasi petani dalam suatu kelompok atau organisasi maka akan meningkatkan produktivitas petani dan begitu juga sebaliknya, semakin rendah partisipasi maka akan membuat produktivitas menjadi rendah. Norma-norma yang dimiliki bersama antar individu atau kelompok akan memperkuat ikatan sosial 
dan memperkuat kerjasama dalam proses meningkatkan produksi. Modal sosial yang tidak berpengaruh terhadap produktivitas petani kopi yaitu jaringan dan timbal balik.

\section{Saran}

1. Perlu adanya upaya untuk meningkatkan produktivitas petani kopi di LMDH Karamat Jaya Desa Karamatwangi Kecamatan Cisurupan Kabupaten Garut melalui progam pemberdayaan masyarakat maupun progam penyuluhan pertanian terkait optimalisasi penggunaan lahan pertanian untuk penanaman kopi dan pengendalian OPT.

2. Penelitian ini hanya terbatas pada pengaruh modal sosial terhadap produktivitas petani kopi. Perlu adanya penelitian lanjutan terkait penguatan modal lainnya yaitu modal ekonomi, pemasaran produksi kopi garut, dan petani muda.

\section{DAFTAR PUSTAKA}

Badan pusat statistika. (2017). Statistika Modal Sosial 2017.BPS.Jakartaindonesia

Grootaert, C. dkk. (1999). Sosial Capital, Household Welfare and Poverty in Indonesia. Working Papper No. 6. Washington: TheWorld Bank.

Grootaert. (2002). Understanding \& Measuring Sosial Capital A
Multidisiplinary Tool For Practitioners. Working Papper No. 18. Washington: TheWorld Bank.

Harahap, M., \& Herman, S. (2018). Hubungan Modal Sosial Dengan Produktivitas Petani Sayur (Studi Kasus Pada Kelompok Tani Barokah Kelurahan Tanah Enam Ratus Kecamatan Medan Marelan). AGRIUM: Jurnal Ilmu Pertanian, 21(2), 157-165.

Hasibuan, Malayu S.P. (2005). Manajemen Sumber Daya Manusia. Edisi Revisi, Jakarta: Bumi Aksara.

Irma Suwarni. (2011). Ketertarikan antara modal sosial dengan produktivitas pada sentra bawang merah di kecamatan pangalengan kabupaten bandung. (Thesis, Fakultas Ekonomi Universitas Indonesia)

James Coleman. (1990). Foundation of Social Theory. Cambridge: Harvard University Press.

Kholifa, N. (2016). Pengaruh modal sosial terhadap produktivitas petani (Studi kasus di Kecamatan Cilacap Utara Kabupaten Cilacap). Jurnal Pendidikan dan Ekonomi, 5(2), 89-97.

Mubyarto dan Kartodihardjo, (1990). Pembangunan Pedesaan di Indonesia. Liberty, Jakarta.

Sugiyono. (2012). (Cetakan ke-17). Metode Penelitian Kuantitatif Kualitatif dan R\&D. Bandung : Alvabeta, CV.

Soerjono Soekanto. (2005). Sosiologi Suatu Pengantar. Jakarta: PT Raja Grafindo

Tambunan, D. E., Satmoko, S., \& Gayatri, S. (2018). Pengaruh Modal Sosial Terhadap Produktivitas Petani Sayuran Organik Di Desa Batur, Kecamatan Getasan, Kabupaten Semarang. Jurnal Ilmu-Ilmu Pertanian, 25(1). 